\title{
Magdalena Lapińska
}

The University of Bialystok

\section{A Game of Thrones - a New Classic?}

\begin{abstract}
The following paper depicts George R. R. Martin's A Game of Thrones as a novel worthy of receiving the title of a classic. Classics are presented as a section of literature to which permission is granted based on particular criteria which is full of prejudice, especially towards specific genres. Fantasy is shown as a genre having particular difficulties entering the 'restricted' section of literature reserved for classics. A Fantasy novel $A$ Game of Thrones is analyzed in terms of characters and symbols discerned as the paramount elements of a classic. Presented characters and symbols demonstrate that A Game of Thrones possesses the elements characteristic of all classics and despite the fact that it belongs to genre of Fantasy it is feasible it will become a classic.
\end{abstract}

Key words: classics, Fantasy literature, A Game of Thrones

Classics and "the canon" have always been the elite of the literary world, groups whose new members have to meet certain criteria to become a part of high culture. Over the years, newcomers joining "the clique" shared many of the key features characteristic of the existing members of the group - a fact contributing to divisions within and between genres of literature. The invisible line categorized books from particular genres either as potential classics or as popular literature unworthy of the name classic.

One genre whose books have been frequently overlooked as contenders for the "title" of classic is Fantasy. Although we can find some classics within the genre, for example The Hobbit by J.R.R. Tolkien, Fantasy was "once upon a time, largely ignored by the literary world, dismissed as beneath notice" (Mandala 2010: 2). Admittedly, many Fantasy novels were not worthy of becoming classics, but because of the existing prejudice against the whole genre many great novels have not been able to cross the line dividing popular literature and Literature with a capital ' $L$ '.

When deciding which books to classify as classic, different critics and scholars have different criteria they rely on. I believe that when making the choice they should refer to "a definition generous enough to include all masterpieces of every school and time" (Erskine 1967: 182) and try to extract elements characteristic of most recognized classics, despite the genre they adhere to. In my opinion these common elements are great characters and symbols.

A Game of Thrones by George R. R. Martin is one book that adheres to the overlooked genre of Fantasy. Although first published in 1996, it became immensely famous a couple of years ago when it was made into a TV series. Becoming a world-wide bestseller, though, did not give it a fighting chance as a contender for the title of classic but rather caused it to be dismissed as "popular" literature unworthy of the attention of serious critics. However, if we take a closer look at the novel we will discover that it is full of the rich characters and symbols which make it a candidate in line to become a new member of the elite.

Characters in a novel are important to readers, as those individuals can become friends, enemies, or even embodiments of life lessons. Eddard Stark and Robert Baratheon are characters whose stories show readers what love can do to a person's life. Robert's life is deprived of love. He lost his fiancée, then entered a political marriage which ultimately led to his tragic death as the wife who hated him stood behind his demise. Unlike Robert's, Eddard's 
life was filled with love. Although Eddard, the same as Robert, entered an arranged marriage, he and his wife came to love each other. At the beginning of his marriage, however, love led him to sacrifice his moral values as he fell in love with a woman who was not his wife and fathered a son with her. Eddard's life was also filled with parental love, which in the end led him to sacrifice his morality once again and unfortunately was an indirect cause of his death. Touching upon the topic of parental love we cannot overlook Cersei Lannister and Catelyn Stark, who both show readers the lengths to which a mother will go to protect her children, from personal sacrifice to committing a crime.

One character who we can treat as an embodiment of a life lesson is Daenerys Targaryen. The lesson which her character presents is that even the best of intentions and good deeds can bring the worst consequences (she lose both her child and her husband).Nonetheless, she should not be treated as merely the personification of a lesson: she is a complicated character. Daenerys is a person who despite a traumatic childhood and constant abuse manages to stand up for herself and subsequently impose her will upon others.

The characters of Tyrion Lannister and John Snow are foils who deal quite differently with the one thing they have in common: being an outcast. Both characters are outcasts as far as their families and the society are concerned. Tyrion Lannister is a dwarf; John Snow is a bastard. Tyrion deals with his situation by accepting who he is and making the best of what life throws at him. He is aware of his body's limitations and concentrates on his best feature, his intelligence: "My mind is my weapon. My brother has his sword, King Robert has his warhammer, and I have my mind .. ." (A Game of Thrones p.123-124). On the other hand, we have John Snow who does not agree with the hand that life has dealt him and desperately seeks a place where he would belong. He finds his place in the brotherhood of the Night's Watch. Living among other outcasts, separated from the society which treated him as a citizen of the second category, he can hide and try to forget about what makes him an outcast: his illegitimacy. The book portrays other characters as well who would not be categorized as ordinary citizens. King Aerys was mentally ill, Brann is paralyzed, Varys is a eunuch, and Khal Drogo is in a persistent vegetative state when the novel is coming to an end. The portrayal of each of these characters raises a host of questions about important issues; for instance, Khal Drogo's death brings out the issue of euthanasia.

Not only the well developed characters, but also its numerous symbols make A Game of Thrones a novel worth noticing. The Wall functioning as one of the borders of the Seven Kingdoms is among the symbols present in the book. One possible explanation as to what The Wall can symbolize is that it is a material manifestation of the fears of the people living in the Seven Kingdoms. People afraid of the unknown build walls separating them from things they fear. In the Seven Kingdoms what citizens fear the most is what lies Beyond the Wall. And the Wall is what keeps them safe: "On the other side were monsters and giants and ghouls, but they could not pass so long as the Wall stood strong" (A Storm of Swords p. 759). In our reality people also build walls of fear. We can find many examples of those walls. For instance, following the terrorist attack on the World Trade Centre in the USA in 2001 and as a result of the 'War on Terror' a "culture of fear" (Brzeziński 2007) was shaped. Many in the West built a metaphorical wall separating them from Arabic culture. Arabic culture became a feared monster much as the Wildings are what citizens of the Seven Kingdoms dread. It can be said that Martin has taken something which in our world appears only in a non-material form and given it substance and shape. Even the Berlin Wall was a material manifestation of the Soviet Union's fear of emigration on a great scale. The Wall in Martin's novel is a symbol of the barriers people set to keep their fears at bay.

The throne traditionally is a symbol of power and the Iron Throne is no exception. However, the fact that the seat is constructed from the weapons of past enemies allows the 
reader to presume that it might also symbolize something different. The Iron Throne can symbolize past enemies as the blades from which the seat is built serve as a constant reminder of defeated foes. Although the throne was forged a long time ago, its blades are still sharp, which can symbolize the notion that the past is never truly behind us and that issues we thought were resolved can always come back to hurt us all over again, just as the weapons of the defeated enemies can still cut the person sitting on the Iron Throne. The Iron Throne can also symbolize the idea that those in a position of power should never be able to feel too comfortable with the authority they possess. We may can presume that this is one of the symbolic ideas of the Iron Throne, as the king who originally had it made said that „A king should never sit easy" (A Game of Thrones p.462).

Symbolism can also be discovered in the work's seasons, which are quite different from those in our reality. In the world of A Game of Thrones one season can continue for years, decades even, but what is more important than the seasons' duration is the fact that they symbolize the phases of life. Summer symbolizes childhood. Bran is referred to as a ,sweet summer child (A Game of Thrones p. 240) and when John and other recruits of the Night's Watch are pointed out to be young and inexperienced, they are called "green and stinking of summer" (A Game of Thrones p. 444). Since the summer is associated with childhood, winter is to symbolize adulthood. Stark's motto "Winter Is Coming" (A Game of Thrones p. 813). looms over everyone and seems to say that childhood always passes and adulthood is inevitable. The changing of the seasons, which the reader can observe throughout the novel, can symbolize the rite of passage from one phase of life into another. Summer changes into winter just as children turn into adults. The shifting of the seasons symbolizing the phases of life reinforces one of the important themes in the novel: how individuals deal with the coming of age. Readers can observe how some of the characters in the novel grow up as the seasons change. The transformation from child into adult is most visible in the character of Robb Stark, who turns from a boy playing with wooden swords to a man commanding an army.

More symbolism can be discovered in the way crows and ravens are presented in the novel. In the Seven Kingdoms there is a saying: "Dark wings, dark words" (A Game of Thrones p. 254), which clearly shows that people treat crows and ravens as a bad omen. The men of the Night's Watch are referred to as crows, not only because they always dress in black, but we can assume that it is because crows also symbolize solitude (Cirlot 1971). The men of the Night's Watch are sworn into the brotherhood for life, vowing never to have families and to protect the realm at all costs, which means a life in solitude. Crows can also symbolize the notion of seeing the larger picture. Brann has 'prophetic' dreams in which a three-eyed crow shows him what happens in distant places as well as what is yet to come. The crow's third eye presumably means that the animal can see more than others and helps Brann understand what is truly important, whereas others are only able to see what is right in front of them.

There are many more symbols which readers may find in the novel. We could look into the symbolism of the sigils of the Houses, or the dragons and their "resurrection", as A Game of Thrones is full of things whose meaning is open to interpretation if we just look beneath the surface.

Fantasy as a genre is often sneered upon by critics, but certain authors like Tolkien or Terry Pratchett have transcended the stereotype. Although A Game of Thrones has the great characters and rich symbols characteristic of most classics, only time will tell if it is also destined to become one. 


\section{References}

Brzeziński, Zbigniew. Terrorized by 'War on Terror', March 25, 2007 www.washingtonpost.com/wp-dyn/content/article/2007/03/23/AR2007032301613.html

Cirlot, J.E. 1971. A Dictionary of Symbols. (2 ${ }^{\text {nd }}$ edition). London: Routledge \& Kegan Paul.

Erskine, John. 1967. The Classical Rule, Lectures on Literature New York: Books for Libraries Press, 177-202.

Mandala, Susan. 2010. Language in Science Fiction and Fantasy. New York; London: Continuum.

Martin, George R. R. 2011. A Game of Thrones. New York: Bantam Books.

Martin, George R. R. 2011. A Storm of Swords. New York: Bantam Books. 